\title{
English Teachers' Use of Learners' L1 (Arabic) in College Classrooms in Kuwait
}

\author{
Sulaiman Alrabah ${ }^{1}$, Shu-hua Wu ${ }^{1}$, Abdullah M. Alotaibi ${ }^{1} \&$ Hussein A. Aldaihani ${ }^{1}$ \\ ${ }^{1}$ Language Center, College of Business Studies, Public Authority for Applied Education and Training, Kuwait \\ Correspondence: Shu-hua Wu, Language Center, College of Business Studies, Public Authority for Applied \\ Education and Training, Kuwait. Tel: 965-2231-5798. E-mail: wu104ohio@yahoo.com.tw
}

Received: October 23, 2015 Accepted: November 28, 2015 Online Published: December 1, 2015

doi:10.5539/elt.v9n1p1

URL: http://dx.doi.org/10.5539/elt.v9n1p1

\begin{abstract}
This study investigated English teachers' use of learners' L1 (Arabic) in college classrooms in Kuwait. The purpose of the study was three-fold: (1) to describe the functions for which L1 was employed by the teachers, (2) to explore the affective, sociolinguistic, and psycholinguistic factors that may have led teachers to use L1 in L2 teaching, and (3) to measure the teachers' attitudes toward using L1 in teaching English as a foreign language (EFL). 60 EFL teachers at the Language Center in a college in Kuwait agreed to participate in the study. Data collection methods included recorded interviews and a grounded survey that was derived from the data of the interviews. Data analysis methods utilized Ethnograph 6.0, a software program, in order to search for common patterns of L1 use in the teachers' interviews. Analysis of the survey utilized the Microsoft Excel Software Program to generate the means, percentages, and standard deviations for each of the survey items. The survey results indicated that the teachers used L1 in L2 classrooms as a teaching tool and for classroom management. The participating teachers also indicated that affective, sociolinguistic, and psycholinguistic factors have contributed to their L1 use in L2 teaching. However, the results also showed that the participating teachers exhibited mostly negative attitudes toward L1 use in L2 teaching. This contradiction between classroom practice and attitudes entailed implications for language teacher education programs to better equip EFL bound graduates with appropriate teaching strategies and classroom techniques to use L1 in appropriate ways in the EFL classroom.
\end{abstract}

Keywords: L1 use, L2 pedagogy, EFL, affective factors, teachers' attitudes, classroom management

\section{Introduction}

English is used exclusively as the language of instruction in language classrooms where English is taught as a second language (ESL) as well as those in which English is taught to speakers of other languages (TESOL). Several research studies in EFL settings have, however, revealed that when teachers of English share the same first language (L1) background with their students, they use L1 alongside the second language (L2) to teach English (e.g., Rabbidge \& Chapell, 2014). Kaneko (1990), for example, reported that in an English class in Japan, an average of $40 \%$ of speaking time in class was conducted in Japanese. A growing number of researchers have, moreover, proposed that the appropriate use of L1 in L2 classrooms can play a positive role in both teaching and learning L2. Advocates of this position (e.g., Atkinson, 1993; Cook, 2013; Liu, 2008) have argued that the appropriate use of L1 as a teaching tool can play a supportive rather than a detrimental role in the L2 learning process. To further support the use of L1 alongside L2 in EFL settings, a number of studies have empirically addressed the use of L1 and its potential effects on students' vocabulary acquisition (Liu, 2008) and grammatical acquisition (Vaezi \& Mirzaei, 2007). Results from these studies indicated that L1 use to teach L2 vocabulary and grammar had proven benefits on the learners' L2 acquisition. Moreover, Storch and Aldosari (2010) have shown that pair and group work can be conducted in EFL classrooms without worrying about students' over-reliance on their $\mathrm{L} 1$ to participate in class activities.

L1 use in L2 teaching, however, continues to be a controversial issue. Researchers on second language acquisition (SLA) support a position of maximizing L2 and avoiding L1 in language classrooms (e.g., Chambers, 1991; Duff \& Polio, 1990; Ellis, 1994; Franklin, 1990; Turnbull, 2001). They argue that when language teachers use too much L1 in the classroom, they can deny learners adequate exposure to L2 input which can have detrimental effects on L2 learning and may delay L2 acquisition. They, moreover, suggest that L2 use through the provision of "comprehensible input" (Krashen, 1985), and opportunities for "interaction" in the language 
classroom (Long, 1983) are more conducive to successful second language acquisition than relying on L1 to teach L2. Ellis (1994), for example, proposed that an "acquisition-rich" classroom environment must provide the learner with ample exposure to L2 input and adequate opportunities for negotiation of meaning in the L2 through group work and problem-solving tasks. Advocates of L1 use (e.g., Atkinson, 1993; Cook, 2013; Liu, 2008) do not dismiss the rewards of learners' exposure to L2, but they prefer responsible L1 use which can save classroom time to be allocated to other equally-important activities. For example, L1 could be used to check for comprehension, give instructions, organize tasks, maintain discipline, build rapport, and explain difficult lexical items and grammatical rules and concepts (Cook, 2013). Therefore, the issue of L1 use in L2 teaching continues to be unresolved. There is thus a need for more research to explore the potential benefits and drawbacks of L1 use on teaching and learning processes in a country where English is taught as a foreign language such as Kuwait.

The present study was conducted to explore the role of L1 in L2 teaching by EFL college-level teachers in Kuwait. One aim was to study the kinds of functions for which L1 was employed in the L2 classroom. Another aim was to go beyond a description of the functions of L1 use to a consideration of the factors that may contribute to a teacher's decision to use L1 alongside L2 in the classroom. The third aim was to explore the teachers' attitudes toward using L1 in their L2 classrooms. The study was, therefore, guided by three research questions:

1) What were the functions for which the EFL college-level teachers employed L1?

2) What were the factors that contributed to the EFL college-level teachers' use of L1?

3) What were the attitudes of the EFL college-level teachers toward L1 use in L2 teaching?

\section{Review of the Literature}

This review is organized into four sections. The first section explores studies related to EFL in Kuwait. The second section reviews studies that described the functions for which L1 was employed by language teachers in L2 teaching. The third section explores the factors leading English teachers to use L1 in the language classroom, and the fourth section deals with teachers' attitudes towards using L1 in the language classroom.

\subsection{EFL in Kuwait}

The teaching of EFL in the Kuwaiti public school system was introduced after the independence of Kuwait in the early 1960s. English was then a school subject at the intermediate and secondary school levels which meant students took English from the age of ten to the age of eighteen. During the year 1994, English was introduced as a school subject at the primary school level which meant Kuwaiti students study English from age six to age eighteen. Twelve years of learning English, it was believed, can result in better learning outcomes and higher achievement than before. However, a study that investigated the English language curriculum in Kuwait found that a large percentage (i.e. 78.87\%) of college-bound secondary school graduates performed poorly on the English placement test (EPT) for the college system during the academic year 2012-2013. According to Alotaibi et al. (2014), out of a total of 5,614 students who took the EPT that year, only 1,186 passed the test (p. 441). There was a need, therefore, to offer a large number of remedial English courses for the remaining 4,428 students to improve their proficiency in English in order for them to cope with the demands of more advanced English courses at the college-level. These students' low proficiency levels in English can be one of the reasons EFL Kuwaiti college-level teachers may use Arabic (L1) to teach English (L2). Through using the L1, the teachers accommodate the low proficiency of the students. A similar situation took place in other foreign language settings such as Canada and South Korea. For instance, in a study conducted to investigate L1 use in a class of German as a Foreign Language (GFL) in an English-speaking Canadian university, De la Campa and Nassaji (2009) found that "students' low level of German skill was a major factor why the two instructors chose to use L1 in class" (p. 753). Moreover, in South Korea, Rabbidge and Chapell (2014) conducted a study to explore Korean English teachers' classroom language use in South Korean elementary schools. They found that, despite a Ministry of Education directive to "teach English through English" (TETE), most of the teachers used Korean (L1) to teach English at the elementary schools. The South Korean teachers explained that the students have not yet acquired adequate English vocabulary and grammar to cope with the demands of TETE. Results from these studies suggest that there is a relationship between students' low levels of proficiency and teachers' use of L1 in the language classroom.

\subsection{Functions of L1 Use in L2 Teaching}

A number of researchers (e.g., Atkinson, 1993; Aurebach, 1993; Cook, 2013; De la Campa \& Nassaji, 2009) suggested that L1 can be used appropriately to perform a variety of functions in the language classroom, such as 
checking for comprehension, giving instructions and explaining lexical items and grammatical concepts. So, rather than relying exclusively on the L2 to perform these functions, the L1 can be used as a teaching tool alongside the L2, but not substituting L2 altogether. Several functions were suggested to teachers in which L1 can be used in the classrooms. Atkinson (1993), for example, has listed appropriate uses for L1 in the L2 classroom that included eliciting language, using translation, and testing. Auerbach (1993), moreover, suggested L1 can be used for negotiating the syllabus, record keeping, classroom management, language analysis, and teaching phonology, morphology, and spelling. Cook (2013) also proposed several functions for using L1 in L2 teaching, such as conveying and checking the meanings of words and sentences, explaining grammar, organizing the class, organizing tasks, maintaining discipline, contact with individual students, and testing. Moreover, De la Campa and Nassaji (2009) found that L1 was used for translation, L1-L2 contrasts, evaluation (L1 utterance used to evaluate students' contributions), activity instruction, setting the activity objective, elicitation of student contributions, personal comments, comprehension checks, classroom management, administrative issues (e.g., exam announcements), repetition of students' utterances, reaction to students' questions in L1, humor, code-switching, code-mixing, and using L1 words from L1 culture. These results suggested that L1 can play a complementary role to the L2 especially in EFL contexts where the teacher shares the same L1 background with the students.

\subsection{Factors behind L1 Use in L2 Teaching}

Studies on L1 use have indicated that affective, psycholinguistic, and sociolinguistic factors have contributed to L1 use in the L2 classroom. Language teachers are, however, not always aware of the full range of factors that contribute to L1 use in a given classroom. De la Campa and Nassaji (2009), for example, stated that "the instructors were aware of some of the factors that may have affected their L1 use in general, but they were not aware of some others until they were shown episodes of their teaching" (p. 753). Therefore, teachers' decisions to switch from L2 to L1 within the context of the classroom can be motivated by a variety of affective, sociolinguistic, and psycholinguistic factors that may contribute to their L1 use in the L2 classroom.

\subsubsection{Affective Factors}

When taking students' low levels of L2 proficiency into consideration, a teacher's insistence on using L2 exclusively can lead to a stressful classroom environment for students. Meyer (2008) alternatively indicated that "the primary role of the students' L1 in the language classroom is lowering affective filters" (p. 147). He argued that for L2 input to be made comprehensible, L1 may be used by the teacher to ensure a low affective filter among the students, thereby facilitating L2 acquisition. Schweers (1999) further argued that there were pedagogical as well as affective factors contributing to L1 use in the L2 classroom. Nevertheless, Copland and Neokleous (2011) stated that "decisions about when to use L1 and L2 are complex and seem to be based on both affective and cognitive factors" (p. 6). They elaborated that in terms of affective factors, teachers responded to their students' contributions, whatever language they used, in what seemed to be an effort to create a stress-free learning environment. These results show that using L1 alongside L2 can, therefore, enable teachers to create a relaxed classroom experience where the L2 can be learned more effectively than using L2 as the only language of instruction.

\subsubsection{Psycholinguistic Factors}

During their attempts to simplify L2 input to adjust to learners' proficiency levels, teachers in EFL settings often use L1 to make themselves more comprehensible. Therefore, the language that teachers address to language learners is often simplified and the degree of simplification relates to the learners' levels of proficiency. According to Ellis (1992), an adult native speaker's deliberate process of simplifying the complexity of her/his speech to fit the level of the child-hearer is similar in many ways to a teacher's simplifying her/his talk to adjust to the students' level of proficiency in the L2. Within a language classroom, input simplification may include the teacher using L1 to accommodate the low proficiency of the students. De la Campa and Nassaji (2009), for example, stated that "students' low level of German skill was a major factor why the two instructors chose to use L1 in class" (p. 753). Experienced EFL teachers, it seems, have an intuitive feel about their students' proficiency levels and they adjust their L2 input accordingly to accommodate students including the use of L1 in L2 teaching.

\subsubsection{Sociolinguistic Factors}

An EFL teacher's sense of identity as an individual is bound up within his/her native language. Using L1 in the L2 classroom can be closely related to a teacher's sense of identity which includes one's native language. For example, Kaneko (1990) found that in a classroom where both teacher and students were Japanese, nearly $40 \%$ of total speaking time in class was conducted in Japanese. According to Macaro (1997), even though a teacher of English in an EFL context may share the same L1 with her/his students, the teacher is practically adopting a 
"surrogate" identity in class - that of a native speaker of English. However, the students can tell that she/he is a member of their own cultural group. Schweers (1999) suggested that students can identify better with a teacher who speaks to them in their own language. He added, "I also feel very much in touch with them as we share a common language when necessary" (p. 9). When the teacher accommodates the students' sense of national, linguistic and cultural identity by using the students' L1, he/she can increase rapport with students which may facilitate the L2 acquisition process. Moreover, teachers' L1 use can be seen as a form of convergence to the students' speech patterns (Giles \& Ogay, 2006). For instance, in De la Campa and Nassaji (2009), the two instructors switched to L1 to accommodate their learners' lack of proficiency in the L2. This process can be interpreted as convergence to students' speech patterns in the social setting of the classroom.

\subsubsection{Teachers' Attitudes toward Using L1}

The issue of using L1 while teaching L2 represents a contradiction facing EFL teachers as they go about their daily task of teaching L2. On the one hand, teachers employ L1 for a variety of functions as a language teaching tool and for classroom management. On the other hand, they seem to have negative attitudes toward L1 use in L2 teaching. This contradiction is compounded by the apparent disparity between teachers' stated beliefs and their actual classroom practices. Copland and Neokleous (2011) concluded that teachers' desires about L1 use were clearly in conflict with their classroom practice. Researchers on L1 use have long been aware of this contradiction in professional behavior which has led many EFL teachers to feelings of guilt (Copland \& Neokleous, 2011), frustration (Cianflone, 2009), or professional inadequacy (Cook, 2013). Exploring teachers' attitudes toward L1 use can, therefore, provide more insights about the apparent disparity between teacher's attitudes and their actual classroom practices.

Thus, there was a need to conduct the present study of English teachers' use of L1 to understand the functions in which they used L1 in the classroom, and to investigate the factors that contributed to L1 use as well as to measure the teachers' attitudes toward L1 use in the L2 classroom.

\section{Methodology}

\subsection{The Setting}

Data were collected from the teachers of English at the Language Center serving five colleges in Kuwait: Business, Education, Technology, Health Sciences, and Nursing. The mission of the college system in Kuwait is to prepare students for middle-management positions at all sectors of the Kuwaiti economy. Graduates work as bank clerks, primary school teachers, engineers in the petroleum industry, health workers, and nurses. As English has established itself as the language of Banking, Engineering, medicine, and Education, there is an obvious need for graduates to master all the English language skills to thrive in their chosen fields of study. Therefore, the language center offers English for specific purposes (ESP) courses to serve the labor market and to cater for the language needs of students in each of the five colleges. Upon admission to the college system in Kuwait, students need to go through an English placement test (EPT). Students who do not achieve the passing grade of $60 \%$, are admitted to a remedial course in English to increase their proficiency levels. The English remedial course is a pre-requisite for a general English course which is also a pre-requisite for a series of two ESP courses in the students' specialty area.

\subsection{The Participants}

English teachers working at the language center have a minimum qualification of a Master of Arts degree (M.A.) in TESL, TESOL, TEFL, or other cognate fields of study. To qualify as teachers at the Language Center, they need to earn their degrees from an accredited university in the United Kingdom, Australia, or the United States of America. The researchers wrote a solicitation letter to the director of the Language Center requesting access is facilitated to the teachers. Access was granted by the director of the Language center who facilitated contact with the more than 70 teachers of the Language Center. The researchers then wrote a solicitation letter to each of the teachers explaining the purpose of the research and assuring them of confidentiality and anonymity and advising them they can stop participating in the study at any time of their choosing without giving any reasons to the researchers for their decisions. The teachers were also assured that any data collected will be used only for the purposes of the study. A total of 60 full-time English teachers agreed to participate in the study. Upon deciding to participate in the study, each teacher was asked to sign a letter of "informed consent" explaining to them what they needed to do to participate in the study.

\subsection{Data Collection}

Interviews with 15 teachers were first recorded and later transcribed. The corpus of recorded interviews included 15 hours collected over two months. The researchers then designed a "grounded" survey (Strauss \& Corbin, 
1997) according to the data obtained from the interviews. In other words, the interviews were used by the researchers to search for commonalities among the participating teachers' patterns of L1 use (Bazeley, 2013). These common patterns were then used to generate the 30 items of the survey instrument. From February to June, 2015, the survey was distributed among the English teachers of the Language Center $(\mathrm{N}=60)$, where $\mathrm{N}$ represents the number of teachers who responded to the survey. The rate of non-respondents was $2 \%$.

\subsection{Data Analysis}

Interview data were categorized into three categories following the focus of the study as determined by the research questions. Data analysis generated the common patterns and themes shared by the teachers to describe (1) the functions for which L1 was employed during English lessons, (2) the factors that contributed to L1 use in their classrooms, and (3) their attitudes toward L1 use in the classroom. Categories were generated using the software program Ethnograph 6.0 (Seidel \& Clark, 1984) to search for the common patterns of L1 use in the teachers' interviews. The category system of the functions, factors, and attitudes was refined and an inter-rater reliability check was conducted by the researchers to ensure a high degree of agreement $(95 \%)$. The survey instrument was then distributed among the participating teachers. The Microsoft Excel software program was employed to generate the descriptive statistics such as means, standard deviations, and percentages for each of the survey's thirty items. Three tables were generated to display the numerical data for each of the three research questions of the study.

\section{Results}

The study had three aims: to (1) explore the functions for which teachers employed L1 as a teaching tool during their English lessons in college classrooms in Kuwait, (2) describe the factors that contributed to L1 use by L2 teachers, and (3) measure the teachers' attitudes toward the use of L1 in the L2 classroom. In order to determine the functions of L1 use, the researchers examined all the interviews in the database for the functions for which the L1 was employed by the teachers in their particular teaching contexts. These were divided into two sub-categories: teaching tool and classroom management. The factors that contributed to L1 use were divided into three sub-categories: affective, sociolinguistic, and psycholinguistic factors. The teachers' attitudes toward using L1 were divided into two sub-categories: positive and negative attitudes.

\subsection{Functions of L1 Use}

The L1 had dual functions in the L2 classroom: the first function of L1 use was as a teaching tool and the second function was classroom management.

functions employed L1 as a teaching tool, and the second six functions employed L1 for classroom management. However, the frequencies of these functions were varied. The participating teachers mostly agreed that they employed L1 as a teaching tool, such as explaining the meanings of difficult L2 words, comparing the grammatical rules of the L2 to familiar ones in the L1, and using L1 to explain new reading passages. As a tool for classroom management, the teachers agreed that they used L1 for giving instructions during test administration, maintaining discipline in class, and taking students' attendance.

Table 1. Functions of using L1 in L2 teaching

\begin{tabular}{lcccc}
\hline Functions of L1 Use & \multirow{2}{*}{ Mean } & SD & \multicolumn{2}{c}{ Item Responses } \\
\cline { 4 - 5 } Teaching Tool & & & & Disagree \\
\hline 1. Explain the meanings of difficult words & 3.58 & 0.38 & $67.24 \%$ & $32.76 \%$ \\
2. Compare and contrast grammatical rules in L1 and L2 & 3.49 & 0.62 & $48.28 \%$ & $51.72 \%$ \\
3. Explain the meanings of reading passages & 3.18 & 0.46 & $50.00 \%$ & $50.00 \%$ \\
4. Explain grammatical rules and concepts & 3.07 & 0.87 & $29.31 \%$ & $70.69 \%$ \\
5. Correct students' errors in class & 2.71 & 0.69 & $65.52 \%$ & $34.48 \%$ \\
Classroom Management & & & & \\
1. Give instructions for students during test administration & 3.44 & 0.33 & $55.17 \%$ & $44.83 \%$ \\
2. Maintain class discipline & 3.32 & 0.48 & $52.76 \%$ & $47.24 \%$ \\
3. Take students' attendance & 3.17 & 0.26 & $60.34 \%$ & $39.66 \%$ \\
4. Distribute classroom tasks and activities & 3.05 & 0.75 & $43.10 \%$ & $56.90 \%$ \\
5. Remind students to bring their homework and projects & 2.68 & 0.83 & $35.86 \%$ & $64.13 \%$ \\
6. Move from one activity to another in class & 2.46 & 0.80 & $32.76 \%$ & $67.24 \%$ \\
\hline
\end{tabular}

Table 1 identified eleven functions for which the L1 was used by the participating teachers. The first five Within 
the first sub-category of L1 use as a teaching tool, $67.24 \%$ of the teachers agreed that the most frequently used function was explaining the meanings of difficult $\mathrm{L} 2$ words $(\mathrm{M}=3.58)$. The second most frequent function of $\mathrm{L} 1$ use, with $48.28 \%$ of the teachers' agreement, was that of comparing the grammatical rules of the L2 to familiar ones in the L1 $(\mathrm{M}=3.49)$. The third function in which L1 was employed as a teaching tool was explaining new reading passages $(M=3.18)$. The remaining two functions of explaining grammatical rules $(M=3.07)$ and correcting students' errors $(\mathrm{M}=2.71)$ varied among the teachers $(\mathrm{SD}=0.87, \mathrm{SD}=0.69)$ which meant they were not considered by the teachers to be major functions of $\mathrm{L} 1$ use. While $70.69 \%$ of the teachers disagreed with using L1 to explain grammatical rules, $65.52 \%$ of the teachers agreed with using L1 to correct students' errors. Overall consideration of the sub-category of using L1 as a teaching tool seems to be, therefore, consistent with the view that L1 can indeed be a tool in a language teacher's "bag of tricks" (Brown, 2015). Using L1 in this capacity can facilitate students' learning of the L2, especially when taking into account their general low proficiency in English.

Within the second sub-category of L1 functions, classroom management, the teachers agreed that the most frequently used function was giving instructions in $\mathrm{L} 1$ during test administration $(\mathrm{M}=3.44)$. The second most frequently used function in classroom management was maintaining discipline in class $(\mathrm{M}=3.32)$. The third classroom management function was taking students' attendance $(M=3.17)$. The fourth function was distributing classroom tasks and activities $(\mathrm{M}=3.05)$. The fifth function was reminding students of homework and class projects $(M=2.68)$, and the sixth function was using $L 1$ to move from one activity to another $(M=2.46)$. The last two functions of reminding students of homework and projects, and moving from one activity to another received high variation among the teachers $(\mathrm{SD}=0.83, \& \mathrm{SD}=0.80)$. This means that they mostly disagreed with the notion that they employed L1 to perform these functions in class. Generally speaking, these results suggest that L1 was used to perform a facilitative role both to teach L2 vocabulary, reading, and grammar, and for classroom management for class discipline, test administration, and taking attendance.

\subsection{Factors Contributing to L1 Use}

In an effort to account for the factors contributing to L1 use in the language classroom, data analysis focused on the affective, sociolinguistic, and psycholinguistic factors that may have contributed to the participating teachers' use of L1 in L2 teaching.

Table 2 shows two items related to affective factors that contributed to teachers' $\mathrm{L} 1$ use to create a more relaxed classroom environment. In addition, there were three items related to sociolinguistic factors. First, the teachers agreed that their having a language in common with their students was a reason why they used L1. Second, they agreed that students' use of L1 to address their teachers made them respond in the L1 as a form of convergence to adjust to the speech patterns of the students. Third, the teachers disagreed with the statement that using L1 to teach L2 created a natural classroom environment. Furthermore, the four items related to psycholinguistic factors in Table 2 indicated that the teachers acknowledged that modern language teaching methods require L1 use to be kept to a minimum in the English classroom, and that using L1 can deprive students' exposure to the L2. They mostly agreed that it is more efficient to freely switch between L1 and L2 and vice versa in beginning level classes.

Table 2. Factors contributing to the teachers' use of L1 in L2 teaching

\begin{tabular}{|c|c|c|c|c|}
\hline \multirow{2}{*}{ Factors Contributing to L1 Use } & \multirow{2}{*}{ Mean } & \multirow{2}{*}{ SD } & \multicolumn{2}{|c|}{ Item Responses } \\
\hline & & & $\overline{\text { Agree }}$ & Disagree \\
\hline \multicolumn{5}{|l|}{ Affective } \\
\hline $\begin{array}{l}\text { 1. Using English exclusively can contribute to a highly stressful } \\
\text { environment among the students }\end{array}$ & 3.06 & 0.67 & $56.90 \%$ & $43.11 \%$ \\
\hline $\begin{array}{l}\text { 2. Using Arabic promotes a more relaxed environment } \\
\text { Sociolinguistic }\end{array}$ & 3.29 & 0.56 & $67.24 \%$ & $32.76 \%$ \\
\hline 3. Use the L1 as the language in common with students & 3.14 & 0.49 & $63.79 \%$ & $26.20 \%$ \\
\hline 4. The use of $\mathrm{L} 1$ creates a natural classroom environment & 2.48 & 0.96 & $43.11 \%$ & $56.89 \%$ \\
\hline 5. Students use the L1 to address me because it is my L1 & 3.21 & 0.71 & $82.75 \%$ & $17.24 \%$ \\
\hline \multicolumn{5}{|l|}{ Psycholinguistic } \\
\hline 6. Using L1 can increase students' learning opportunities of English & 2.58 & 0.81 & $48.27 \%$ & $51.62 \%$ \\
\hline $\begin{array}{l}\text { 7. In beginning levels, I find it efficient to freely switch from Arabic to } \\
\text { English and vice versa }\end{array}$ & 2.87 & 0.85 & $63.79 \%$ & $36.20 \%$ \\
\hline 8. It is useful to have ample quantities of the $\mathrm{L} 2$ in class & 3.43 & 0.50 & $100.00 \%$ & $0.00 \%$ \\
\hline 9. Use of L1 can deprive students' exposure to the L2 & 3.08 & 0.87 & $58.62 \%$ & $41.38 \%$ \\
\hline
\end{tabular}




\subsubsection{Affective Factors}

The responses in the survey indicated that $67.24 \%$ of teachers agreed that using the students' L1 puts students at ease by creating a less stressful classroom environment $(\mathrm{M}=3.06)$. If teachers restricted their speech to using $\mathrm{L} 2$, $56.90 \%$ of the teachers agreed that the classroom can become a stressful environment $(M=3.29)$. This means that the teachers as a group could tell that using L1 can be a means of lowering their students' affective filters along with their feelings of inhibition and anxiety while learning the $\mathrm{L} 2$.

\subsubsection{Sociolinguistic Factors}

$63.79 \%$ of the teachers agreed with item 3 related to using L1 because they have a language in common with their students $(M=3.14) .82 .75 \%$ of the teachers strongly agreed with item 5 related to students' use of $\mathrm{L} 1$ to address their teachers. It is not uncommon for students who have low proficiency in the L2 to address their teacher in the L1 thereby making their teacher respond in the $\mathrm{L} 1$ as well $(\mathrm{M}=3.21)$. In this case, L1 use was a form of convergence by the teacher to adjust her/his speech patterns to resemble the speech of low proficiency students. Furthermore, $56.89 \%$ of the teachers disagreed that using L1 while teaching English can create a natural classroom environment $(\mathrm{M}=2.48, \mathrm{SD}=0.96)$. These responses indicated that the teachers believed the context of the $\mathrm{L} 2$ classroom had an effect on their using L1 to teach L2.

\subsubsection{Psycholinguistic Factors}

The teachers unanimously agreed with item 8 which stated that modern language teaching methods require L1 use to be kept to a minimum in the English classroom $(\mathrm{M}=3.43) .58 .62 \%$ of the teachers also agreed with item 9 which stated that using $\mathrm{L} 1$ can deprive students' exposure to the $\mathrm{L} 2$ use $(\mathrm{M}=3.08)$. These responses are consistent with the position of "minimizing L1" in class. However, $63.79 \%$ of the teachers strongly agreed with item 7 which stated that in beginning levels it was efficient to freely switch between $L 1$ and $L 2$ and vice versa $(M=2.87)$. This position is consistent with using $\mathrm{L} 1$ as a form of input simplification to adjust to learners' low proficiency in beginning classes. Only $48.27 \%$ of the teachers agreed and $51.73 \%$ of the teachers disagreed $(\mathrm{M}=2.58, \mathrm{SD}=0.81)$ with item 6 which stated that using L1 can increase students' learning of English. This means they were almost evenly divided over how the LI can be employed constructively as a facilitator of L2 learning. In conclusion, the four items in the sub-category of psycholinguistic factors encapsulate the controversy within the language teaching profession regarding L1 use in the language classroom. On the one hand, some claim that minimizing L1 use will result in better and faster rates of L2 acquisition. On the other hand, others see a useful role for L1 as a teaching tool that can facilitate L2 acquisition. Probably, the teachers' responses reflect the controversy regarding L1 use in L2 teaching.

\subsection{Teachers' Attitudes toward L1 Use}

The teachers' attitudes toward using L1 in teaching L2 can best be characterized as negative on the whole. Results from this study have shown that teachers employed L1 in a variety of functions in the L2 classroom as a teaching tool and for classroom management, and that there were affective, psycholinguistic, and sociolinguistic factors that lead teachers to use L1 in L2 teaching. However, results related to teachers' attitudes indicated that teachers' attitudes toward using L1 in teaching L2 were in opposition to their actual classroom practices

Table 3 describes the teachers' attitudes toward the use of L1 in L2 teaching. 82.76\% of the teachers agreed with item 4 that they felt guilty about the potential loss of L2 exposure in class $(\mathrm{M}=3.16), 72.41 \%$ agreed with item 5 that they used L2 in class with few occasions for using L1 (M=3.02), and $77.49 \%$ agreed with item 7 that the use of $\mathrm{L} 1$ should be kept to a minimum in teaching $\mathrm{L} 2(\mathrm{M}=3.00)$. Moreover, $72.42 \%$ agreed with item 7 which stated that using a lot of L1 made the teacher feel the class was a waste of time. These high rates of agreement showed that most of the teachers felt negatively about L1 use in L2 teaching. However, in response to item 8, teachers varied in their responses with only $41.38 \%$ of the teachers agreeing that the $\mathrm{L} 1$ should be avoided at all cost when teaching L2 $(\mathrm{M}=2.36, \mathrm{SD}=0.97)$ while $58.62 \%$ of the teachers disagreed with this item. This showed that the teachers mostly felt they cannot avoid using L1 at all cost in L2 teaching. Teachers in foreign language contexts including Kuwait are often compelled to using the L1 when learner needs called for its use. 
Table 3. Teachers' attitudes toward the use of L1

\begin{tabular}{lcccc}
\hline Teachers' Attitudes Toward Using L1 & \multirow{2}{*}{ Mean } & SD & \multicolumn{2}{c}{ Item Responses } \\
\cline { 5 - 6 } Agree & Disagree \\
\hline Positive Attitudes & & & & \\
1. L1 is a resource in my teaching repertoire & 2.86 & 0.69 & $75.86 \%$ & $24.14 \%$ \\
2. I feel fully justified in using L1 & 2.55 & 0.96 & $44.83 \%$ & $55.17 \%$ \\
3. Expedient to mix L1 and L2 in large classes & 2.28 & 0.79 & $37.93 \%$ & $62.07 \%$ \\
Negative Attitudes & & & & \\
4. Guilty about the potential loss of L2 exposure & 3.16 & 0.57 & $82.76 \%$ & $17.24 \%$ \\
5. I use English with few occasions for L1 & 3.02 & 0.81 & $72.41 \%$ & $27.58 \%$ \\
6. L1 is kept to a minimum in teaching English & 3.00 & 0.82 & $77.59 \%$ & $22.41 \%$ \\
7. Using L1 a lot makes class a waste of time & 2.88 & 0.87 & $72.42 \%$ & $27.59 \%$ \\
8. L1 use should be avoided at all cost & 2.36 & 0.97 & $41.38 \%$ & $58.62 \%$ \\
\hline
\end{tabular}

As if to underscore their negative attitudes toward L1 use in L2 teaching, most teachers disagreed with statements that were positive toward L1 use. While $75.86 \%$ of the teachers agreed that L1 is a resource that can help students comprehend the meanings of new words $(\mathrm{M}=2.86), 62.07 \%$ disagreed with item 2 on the use of L1 alongside the L2 in large classes $(\mathrm{M}=2.28)$, and $55.17 \%$ disagreed with item 1 which stated "I feel fully justified in using L1 to get on with my lessons smoothly" $(\mathrm{M}=2.55)$. These responses revealed that most of the teachers had negative attitudes toward the use of $\mathrm{L} 1$ in class.

\subsection{Discussion}

The discussion relates the answers to the three research questions of the study to existing studies on L1 use in L2 teaching. The first research question was focused on the functions for which L1 was employed by the participating teachers. The present study found several functions in which L1 was used in the classrooms. For example, the teachers indicated that they employed the L1 as a teaching tool to explain the meanings of difficult words and concepts, compare the grammatical rules of the L2 to those from the L1. The teachers also used L1 to perform a number of classroom management functions including giving instructions during tests by using L1, maintaining discipline in class, and taking students' attendance. A number of researchers (e.g., Atkinson, 1993; Aurebach, 1993; Cook, 2013; De la Campa \& Nassaji, 2009) have also suggested that L1 can be used to perform a variety of functions in the language classroom, such as checking for comprehension, giving instructions and explaining lexical items and grammatical concepts.

The second research question was related to the factors that might have contributed to L1 use by the participating teachers. The teachers indicated that these factors were affective, sociolinguistic, and psycholinguistic in nature. From an affective point of view, the teachers agreed that using English exclusively in the classroom contributed to a highly stressful classroom environment in that students exhibited anxiety, fear, and frustration for not being able to follow what the teacher is saying in English. This was probably due to the students' low proficiency in English. When the teachers moderately used Arabic during the English lesson, however, they noticed that the students were more relaxed and less anxious probably because they could follow what the teacher was saying in class. Meyer (2008) stated that "the primary role of the students' L1 in the language classroom is lowering affective filters" (p. 147). He elaborated that L1 may be used to ensure a low affective filter among the students, thereby facilitating L 2 acquisition. Schweers (1999) also argued that there were pedagogical as well as affective factors contributing to L1 use in the L2 classroom. Moreover, Copland and Neokleous (2011) stated that "decisions about when to use L1 and L2 are complex and seem to be based on both affective and cognitive factors" (p. 6).

From a sociolinguistic perspective, participating teachers' identities and their feelings of who they are and where they come from contributed to their use of L1 in the English classroom. For example, they agreed that their having a language in common with their students was a factor that contributed to their L1 use in the classroom. Schweers (1999) suggested that students can identify better with a teacher who speaks to them in their own language. The teachers also indicated that they converged with their students by using Arabic to respond to students' questions that were posed in Arabic. Teachers' L1 use can thus become a form of convergence to the students' speech patterns (Giles \& Ogay, 2006). The convergence process can be interpreted as an attempt by the teachers to accommodate students' speech patterns in the social setting of the classroom. 
From a psycholinguistic standpoint, the participating teachers indicated that using L1 can deprive students' adequate exposure to the L2. Researchers on second language acquisition (SLA) (e.g., Chambers, 1991; Duff \& Polio, 1990; Ellis, 1994; Franklin, 1990; Turnbull, 2001) have also supported a position of maximizing L2 and avoiding L1 in language classrooms. Moreover, the participating teachers agreed that in beginning level classes it was efficient to freely switch between L1 and L2 and vice versa. According to Ellis (1992), an adult native speaker's deliberate process of simplifying the complexity of her/his speech to fit the level of the child-hearer is similar in many ways to a teacher's simplifying her/his talk to adjust to the students' level of proficiency in the L2.

The third research question addressed the teachers' attitudes toward L1 use. The study found that, for the most part, the teachers exhibited negative attitudes toward using L1 in the English classroom. This finding made coincided with several studies that have indicated similarly-negative attitudes by EFL teachers worldwide. For example, researchers on L1 use in EFL countries have long been aware of these negative attitudes among English teachers toward L1 use which has led many EFL teachers to feelings of guilt (Copland \& Neokleous, 2011), frustration (Cianflone, 2009) or professional inadequacy (Cook, 2013).

This study investigated L1 use by Kuwait EFL teachers at the college level. Its findings are consistent with findings from studies on L1 use that were conducted in other EFL settings such as Italy, South Korea, Japan, and Porto Rico. This shows that the phenomenon of using L1 in EFL settings is quite robust especially when the teacher shares the same language background with the students. More research is, therefore, needed in order to harness the power of L1 and make it work for teaching EFL. There is also a need to specify to teachers when to use L1 and when not to use it as a substitute for L2. This knowledge may be put to good use by EFL teachers who seek to create the right conditions in the classroom for successful language learning for their students.

\subsection{Conclusion}

The results of the study indicated that the participating teachers in varying degrees not only employed L1 as a teaching tool and for classroom management functions, but also varied in attributing affective, sociolinguistic, and psycholinguistic factors that contributed to their L1 use in the L2 classroom. The participating teachers, however, have invariably displayed negative attitudes toward the use of L1 in the L2 classroom. This contradiction between classroom practice and teachers' attitudes has implications for L2 pedagogy and teacher education.

\section{Implications for L2 Pedagogy and Teacher Education}

Several studies (e.g., Rabbidge and Chapell, 2014) have shown that in many EFL classrooms from different language backgrounds, teachers used L1 for more than $40 \%$ of actual class speaking time. This finding calls for language teacher education programs to be more responsive to actual teaching practices in EFL settings. When EFL teachers are ill-prepared to face the use of L1 in their L2 teaching, they develop negative attitudes about their adequacy as English teachers. So, even though L1 use was a distinctive feature of the L2 classroom, the teachers harbored negative attitudes toward L1 use as a whole. Probably because they view themselves as English teachers first and foremost, admitting L1 use for them was tantamount to a confession of professional inadequacy. A better alternative is to train prospective teachers to employ L1 constructively in L2 classrooms. Teacher education programs, therefore, need to provide prospective EFL teachers with proper classroom strategies and techniques on how to harness the L1 in L2 teaching. Moreover, by taking into account the affective, sociolinguistic, and psycholinguistic factors that contribute to L1 use in EFL classrooms, teacher education programs can better prepare teachers to professionally deal with the daily challenges of using L1 as a teaching tool and for classroom management while teaching EFL. There is a need to make teacher education programs that are more relevant to English education efforts worldwide by recognizing the role of L1 in L2 teaching and by instructing prospective teachers on how to employ L1 appropriately in L2 classrooms.

\section{Suggestions for Future Research}

More research is needed to investigate the phenomenon of L1 use to teach L2 in EFL settings. Due to the specificity of EFL teaching where L1 is used frequently when teachers and students share a native language, there is a need for further research to explore the differences between teachers' attitudes and their actual classroom practices regarding L1 use in L2 teaching. There is also a need to explore teachers' reflective thinking on the fact that they are teaching English as their primary task but having to use L1 to adjust to their students' lack of proficiency in L2. Moreover, there is a need to explore teachers' solutions to the problems inherent in students' less than ideal exposure to L2 input as a result of L1 use in L2 teaching. Finally, teachers conducting action research can explore teaching strategies and techniques to compensate for this apparent lack of L2 exposure. For example, the option of using technology to teach L2 can be explored as a possible venue for increasing students' exposure to L2 input. 


\section{References}

Alotaibi, A., Aldiahani, H., \& Alrabah, S. (2014). An investigation of the factors which contribute to low English achievement in secondary schools, as perceived by Kuwaiti and non-Kuwaiti English teachers. European Scientific Journal, 10(25), 440-459.

Atkinson, D. (1987). The mother tongue in the classroom: A neglected resource? ELT Journal, 41(4), 241-247. http://dx.doi.org/10.1093/elt/41.4.241

Atkinson, D. (1993). Teaching in the target language: A problem in the current orthodoxy. The Language Learning Journal, 8(1), 2-5. http://dx.doi.org/10.1080/09571739385200261

Auerbach, E. (1993). Reexamining English only in the ESL classroom. TESOL Quarterly, 27(1), 9-32. http://dx.doi.org/10.2307/3586949

Baker, P. (2006). Jumping the language barrier: the "fifth skill." English Teaching Matters, accessed through Melta News, 2006(6), 22-24.

Bazeley, P. (2013). Qualitative data analysis: Practical strategies. Thousand Oakes: Sage publications.

Brown, D. (2015). Teaching by Principles: An interactive approach to language pedagogy (4th ed.). NY: Pearson Education.

Chambers, F. (1991). Promoting use of the target language in the classroom. Language Learning Journal, 4(1), 27-31. http://dx.doi.org/10.1080/09571739185200411

Cianflone, E. (2009). L1 use in English courses at university level. ESP World, 8(1), 1-5.

Cook, V. (2013). Second language learning and language teaching (4th ed.). New York: Routledge.

Copland, F., \& Neokleous, G. (2011). L1 to teach L2: Complexities and contradictions. ELT Journal, 65(3), 270-280 .http://dx.doi.org/10.1093/elt/ccq047

De la Campa, J., \& Nassaji, H. (2009). The amount, purpose, and reasons for using L1 in L2 classroom. Foreign Language Annals, 42(4), 742-759. http://dx.doi.org/10.1111/j.1944-9720.2009.01052.x

Ellis, R. (1992). The classroom context: An acquisition-rich or acquisition-poor environment? In C. Kramsch, \& S. McConnell-Ginet (Eds.), Text and context: Cross-disciplinary perspectives on language study (pp. 171-186). Lexington, MA: D. C. Heath and Company.

Ellis, R. (2008). The study of second language acquisition (2nd ed.). Oxford: Oxford University Press.

Franklin, C. E. M. (1990). Teaching in the target language: Problems and prospects. Language Learning Journal, 2(1), 20-24. http://dx.doi.org/10.1080/09571739085200371

Giles, H., \& Ogay, T. (2006). Communication accommodation theory. In B. B. Whaley, \& W. Samter (Eds.), Explaining communication: Contemporary theories and exemplars (pp. 293-310). Mahwah, NJ: Erlbaum.

Kaneko, T. (1990). L1 use in foreign language classrooms. Unpublished paper, Temple University, Japan.

Krashen, S. D. (1985). The input hypothesis: Issues and implications. New York: Addison-Wesley Longman Ltd.

Liu, J. (2008). L1 use in L2 vocabulary learning: Facilitator or barrier. International Education Studies, 1(2), 65-69. http://dx.doi.org/10.5539/ies.v1n2p65

Long, M. H. (1983). Native speaker/non-native speaker conversation in the second language classroom. In M. Clarke, \& J. Handscombe (Eds.), On TESOL, 82: Pacific perspectives on language and teaching (pp. 207-225). Washington, DC: TESOL

Macaro, E. (1997). Target language, collaborative learning and autonomy (Vol. 5). Clevedon: Multilingual Matters.

Mishler, E. (1991). Research Interviewing: Context and narrative. Cambridge, MA: Harvard University Press.

Polio, C., \& Duff, P. (1994). Teachers' language use in university foreign language classrooms: A qualitative analysis of English and target language alternation. Modern Language Journal, 78(3), 311-326. http://dx.doi.org/10.1111/j.1540-4781.1994.tb02045.x

Rabbidge, M., \& Chapell, P. (2014). Exploring non-native English speaking teachers' classroom language use in South Korean elementary schools. TESL-EJ, 17(4), 1-18. 
Schweers Jr., C. W. (1999). Using L1 in the L2 classroom. English Teaching Forum, 37(2), 6-9.

Seidel, V., \& Clark. J. (1984). THE ETHNOGRAPH: A computer program for the analysis of qualitative data. Qualitative Sociology, 7(1-2), 110-125. http://dx.doi.org/10.1007/BF00987111

Spindler, G. (2010). Ethnography as participant listening. Ethnography, 11(4), 558-572. http://dx.doi.org/ $10.1177 / 1466138110372587$

Storch, N., \& Aldosari, A. (2010). Learners' use of first language (Arabic) in pair work in an EFL class Language Teaching Research, 14(4), 355-375. http://dx.doi.org/10.1177/1362168810375362

Strauss, A., \& Corbin, J. M. (Eds.). (1997). Grounded theory in practice. Thousand Oaks, CA: Sage.

Turnbull, M. (2001). There is a role for the L1 in foreign and second language teaching, but Canadian Modern Language Review, 57(4), 531-540. http://dx.doi.org/10.3138/cmlr.57.4.531

Vaezi, S., \& Mirzaei, M. (2007). The effect of using translation from L1 to L2 as a teaching technique on the improvement of EFL learners' linguistic accuracy - focus on form. Humanizing Language Teaching, 9(5). Retrieved from http://www.hltmag.co.uk/sep07/mart03.htm

\section{Copyrights}

Copyright for this article is retained by the author(s), with first publication rights granted to the journal.

This is an open-access article distributed under the terms and conditions of the Creative Commons Attribution license (http://creativecommons.org/licenses/by/3.0/). 